\title{
Trip Attraction Model of Land Use for Industrial Area
}

\author{
Imma Widyawati Agustin $^{1 *}$, Budi Sugiarto Waloeya ${ }^{2}$ \\ Department of Urban and Regional Planning, Brawijaya University, Jl. MT. Haryono 167, Malang City, East Java, \\ $65145^{1}$ \\ Department of Urban and Regional Planning, Brawijaya University, Jl. MT. Haryono 167, Malang City, East Java, \\ $65145^{2}$ \\ *Corresponding author: immasaitama@ub.ac.id
}

\begin{abstract}
Malang was a great city that has a diverse industry characteristics and there are spreadly in every district. The goals of industrial vehicles movement is shipping and distribution. There are some problems related to the road's level of service, especially several points of delay and congestion due to the industrial vehicles movement and the limited capacity of the roads. The main purpose of the research is to create the trip attraction model of land use for industrial area as a basis to determine the effect of industrial vehicles movement on the road's level of service in industrial area. The research used industrial distribution mapping, the road's level of service analysis to determine the traffic condition, correlation analysis to determine the influence variables used and multiple linear regression analysis to identify the trip attraction model of land use. The Results showed that the most affected variables of the industrial vehicles movement are the number of employees $\left(X_{3}\right)$ and the delivery frequency $\left(X_{6}\right)$. The trip attraction model is $Y_{\text {industry }}=5.104+0.736\left(X_{3}\right)+1.832$ $\left(X_{6}\right)$ with 94.1 per cent of $R$ square. The road's level of service in Sunandar Priyo Sudarmo Road is C.
\end{abstract}

Keywords-Trip attraction model, Land use, Industrial area

\section{INTRODUCTION}

According to the Presidential Decree of the Republic of Indonesia no. 41 Year 1996, the industry is an economic activity processing raw materials, raw materials, semi-finished materials, and / or finished goods into goods with higher value for its use including industrial engineering design activities.

According Yuliani (2006) are classified by industry classification [1]:

1. Raw materials producing industry, is a company that has the characteristics of core activities as a provider of raw materials needed in the fulfillment of goods or services industry. Supply of raw materials is a process of natural resource resource management.

2. Manufacture Industry, namely the industry that process raw materials into materials with a variety of semi-finished products and finished products.

3. Distributorship Industry, is an industry that has activities in the industry of distributing or distributing semi-finished goods or finished goods.

4. Service Industry, is an industry that has a service function or service that supports the activities of other industries, or directly move to serve consumers.

According to the Ministry of Finance of the Taxpayers' Business Group (2003), the Industrial type classification consists of 23 (twenty three) categories as follows: Food and beverage industry, tobacco processing industry, textile industry, apparel industry, leather industry, leather goods and footwear, wood industry, goods and wood and wicker and other articles, paper industry, paper products and the like, Manufacture of publishing, printing and reproduction of recording media, Coal industry, petroleum refining and processing of natural gas, petroleum products and nuclear fuel, Chemical industry and chemical goods, Rubber industry, rubber yarn And metal products, metal goods industry, metal goods industry except machinery and equipment, machinery and apparatus industries, machinery and office equipment industry, accounting and data processing, other electrical machinery industries and equipments, radio industry, Television and communications equipment and its auxiliaries, the instrument equipment of medicine, measuring equipment, navigation equipment, optical equipment , Clock and bell, motor vehicle industry, transportation equipment industry, four wheel drive or more, furniture industry and other processing industries, recycling industry.

Based on the Industry and Trade Office of Malang City, Industry is grouped into 5 types of Industry classification, as follows:

1. ILMETTA, is an industry engaged in the metal industry, machinery, electronics, textiles and miscellaneous. There is a classification of industrial types in the ILMETTA industry, namely metal base material industry, machinery and agricultural machinery industry, and miscellaneous textile industry.

2. IATT, an industry engaged in transportation and telematics. The IATT industry has detailed industry types, namely the land transportation industry, and the electronics and telematics industries.

3. Agrochemicals. Agrochemical industry is a classification of industries engaged in food processing, drinking, forest products, cigaretts and tobacco. 
4. Industrial Center. Industrial center is a collection of several small industries or households that cluster in a region with the same characteristics. Industrial centers are generally engaged in the production of small and medium scale.

5. Large companies. Large Company is a type of industry that moves with large amount of production. And also the delivery of industrial goods is usually wider national to international.

Meanwhile, if it is in terms of the amount of labor, the industry is classified into large, medium, small, and home industries. The following Classification of Industry Type according to the Central Bureau of Statistics (BPS).

1. Large Industry: Total workforce more than 100 persons

2. Medium Industry: Total Workforce 20 up to 99 Persons

3. Small Industry: The number of Labor 5 up to 19 persons

4. Household Industry: Total workforce less than 5 persons

Industrial activity has several components that are in it as macro coverage that is component of raw material supply, labor until production process (Karyanto, 2004). If further elaborated associated with these components are as follows:

a) Raw Material Supply, it can be explained as a delivery process that comes from raw material to industrial location. Therefore, the location and type of industry should have access that can facilitate it.

b) Labor, more to matters relating to the amount and characteristics of other labor.

c) Production process, it is a process in making raw materials into finished or semi-finished goods in which there is also the process of moving goods from one warehouse to another warehouse.

d) Process Finished Goods Distribution, the distribution process is the process of delivery of finished goods using adequate transportation for distribution to consumers or to other companies.

Transportation is an activity to move people or goods from the place of origin to the destination (Sakti, 2011). The role of transportation for human activities can be said as a bridge between the activities of producers and consumers in trade and other activities. Meanwhile, according to Adisasmita (2010) transportation activities is an activity that can increase the selling value of an item when it was at the destination. Transportation system is a series of network integrity that interconnect between activity systems, transportation infrastructure network, road traffic dimensioning system, pavement to institutional system in transportation. The four things must be balanced and support each other in order to create a transportation system that can serve the needs of society both in all fields (Tamin, 2000).

Trip generation modeling is a stage that estimates the number of movements originating from one zone or land use and the amount of movement that is attracted to a land use or zone. Traffic movement is a function and then land use that generates traffic movement (Figure 1). This traffic generation includes (Tamin, 2000: 13):
1. Traffic leaving a location.

2. Traffic leading to or arriving at a location.

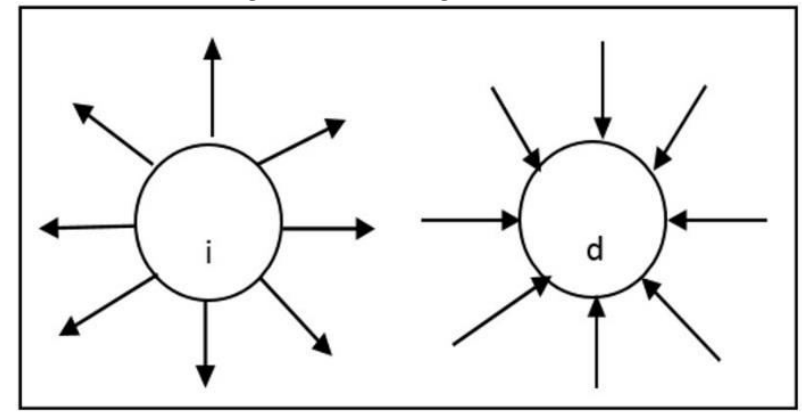

Figure 1. Trip generation and attraction movement Source: Tamin, 2000

The interaction model is used to find out how the relationship between land use system to network infrastructure by using several approaches of function and equation (Figure 2).

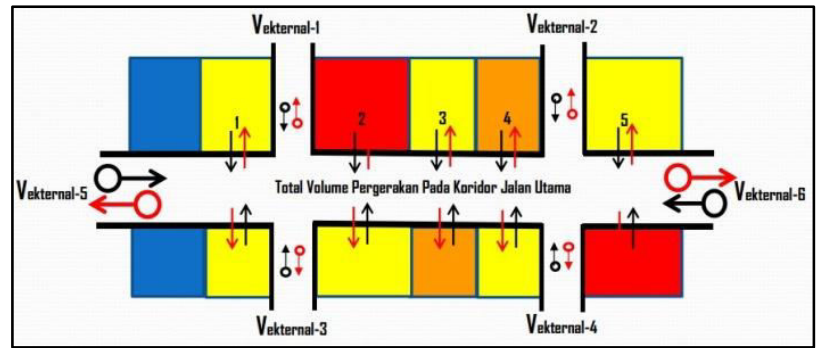

Figure 2. Concept model of land use interaction - road network Source: Waloeya, 2013

To determine the model of the interaction between the land and the road network is done by the formula (Waloeja, 2013):

$$
\text { Vtotal }=\sum \text { internal }+\sum \text { external }(2-1)
$$

Notes:

$\mathrm{V}_{\text {total }}=$ Total volume of vehicle / hour in a corridor Internal $=$ Total volume of vehicle $/$ hour movement from the attraction / land use awakening.

External $=$ total volume of movement of existing external vehicle / clock on a corridor of vehicle / hour movement volume of environmental roads or alleys plus continuous volume of vehicle / clock movement on a corridor.

Before it was obtained how the interaction relationship between land use and vehicle volume on the road is done calculating the model of land use movement along the road. So with it can be known how large the movement in the road.

Road is transport infrastructures covering all parts of the road, including complementary buildings and equipments intended for traffic, located on the surface of the land, above the ground, below the surface of the land and / or water and above the water surface except the railway, Lorries and cable roads (Law No. 34 of 2006). Road classification consists of hierarchy, dimension, road pavement type to side barrier. A road hierarchy is a grouping of paths by function and capacity (Figure 3). According to Government Regulation no. 34 of 2006 on 
Roads, the road hierarchy is divided into the following (Table 1).

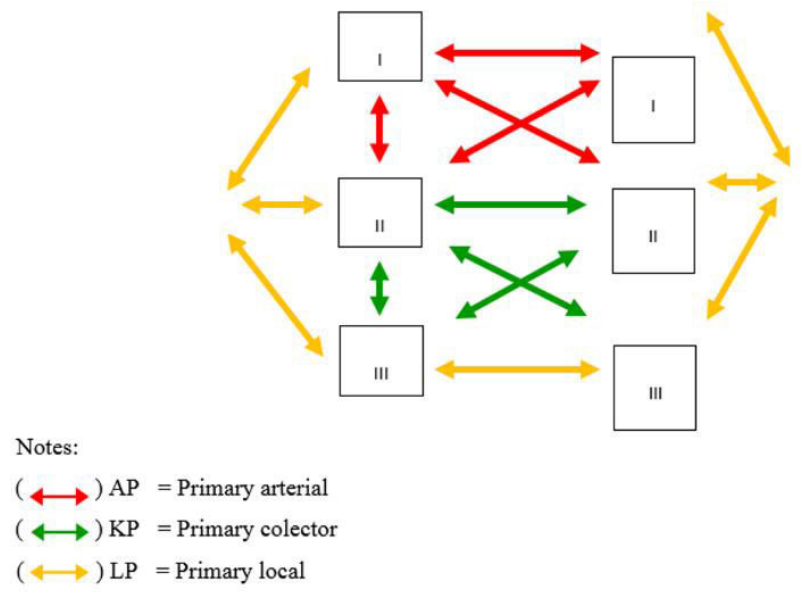

Figure 3. Hierarchy concept of road
Industrial sector in Malang is a sector which control 35.61 per cent of economic activity in Malang City, with biggest donation to local government that is equal to 5.14 Trillyun per year (Spatial Regional Plan in Malang City, 2011-2031).

The existence of the industry is inseparable from the existence of transportation which in the groove of distribution of raw materials and finished goods requires the transporter to be brought to the right destination. Delivery activities by four-wheel vehicles account for $15-25 \%$ of the volume of vehicles weighing on the road (Herzog, 2013). Of course if it is not managed properly then it will be able to cause quite severe traffic problems. One of the visible is the bottleneck. Transport problems have begun since the 1960s and 1970s, some of the problems associated with transportation are congestion, air and sound pollution, accidents and also delays (Tamin, 2000). The source of the problems that occur in transportation comes from several things one of which is the activity of Industry.

Table 1. Terms of the road hierarchy

\begin{tabular}{|c|c|c|c|c|c|}
\hline \multirow{2}{*}{ Hirarki } & \multicolumn{5}{|c|}{ Terms } \\
\hline & Speed & Width & & th free space & Outer Boundary \\
\hline Primary arterial & $60 \mathrm{~km} / \mathrm{h}$ & $+11 \mathrm{~m}$ & $+5 \mathrm{~m}$ & $\pm 1^{1 / 2} \mathrm{~m}$ & \\
\hline Primary collector & $40 \mathrm{~km} / \mathrm{h}$ & $+9 \mathrm{~m}$ & $+5 \mathrm{~m}$ & $\pm 1^{1 / 2} \mathrm{~m}$ & from as $+15 \mathrm{~m}$ \\
\hline Primary local & $20 \mathrm{~km} / \mathrm{h}$ & $+7,5 \mathrm{~m}$ & - & - & from as $+10 \mathrm{~m}$ \\
\hline Primary environmental & $15 \mathrm{~km} / \mathrm{h}$ & $+6,5 \mathrm{~m}$ & - & - & \\
\hline Secondary arterial & $30 \mathrm{~km} / \mathrm{h}$ & $+11 \mathrm{~m}$ & - & - & from as $+20 \mathrm{~m}$ \\
\hline Secondary collector & $20 \mathrm{~km} / \mathrm{h}$ & $+9 \mathrm{~m}$ & - & - & from as $+7 \mathrm{~m}$ \\
\hline Secondary local & $10 \mathrm{~km} / \mathrm{h}$ & $+7,5 \mathrm{~m}$ & $\begin{array}{l}3 \text { whee } \\
\text { (ambul }\end{array}$ & $\begin{array}{l}\text { less than } 3^{1 / 2} \mathrm{~m} \\
\text { rs) }\end{array}$ & from as $+4 \mathrm{~m}$ \\
\hline Secondary environmental & $10 \mathrm{~km} / \mathrm{h}$ & $+6,5 \mathrm{~m}$ & - & - & \\
\hline
\end{tabular}

The existing industry in Malang City has caused quite a few impacts related to transportation. One of the impacts caused is the loading and unloading activities of goods or raw materials that occur can cause delays to congestion. In addition, the activity of industrial workers in the morning (coming) and afternoon (home) using a vehicle causing delays on the road. Therefore, this study was conducted to identify the impact of movement of large and medium industrial vehicles on the performance of existing roads in the City of Malang so it is expected to be used as an evaluation material in industrial planning in the City of Malang related to transportation and problem solving.

\section{METHODS}

The study is located in Malang City which has an area of $110.06 \mathrm{Km}^{2}$. Geographically, Malang is located at 112,060-112,070 East Longitude and 7.0608,020 South Latitude. Administratively, the boundaries of Malang as follows:

North: Singosari District and Karangploso District, Malang Regency.

East: Pakis District and Tumpang District, Malang Regency.

South: Tajinan District and Pakisaji District, Malang Regency.

West side: Wagir District and Dau District Malang Regency.
The reason for choosing Malang City as the study area because Malang City is one of the big city that exist in East Java and it has so many industrial economic development. Determination of industrial blocks spread in some areas in Malang City. Malang also has a high movement of vehicles, both inside and out of town. The existence of these conditions makes the city of Malang interesting to examine the relationship between the movement of industry and the road's level of service (Figure 4).

Figure 5 shows that the research location focus on Sunandar Priyo Sudarmo Road which is determined based on:

1. The Road Class is National Road.

2. Largest number of industrial dispersion.

3. The industry is located near the highway, and it has a direct impact on the road.

The research consists of several stages for problems solving that exist in the study area. Firstly, identify and classify the existing industries in Malang City. Secondly, after classification is finished the determination of the road segment that takes into account several considerations. Thirdly, the calculation and analysis related to the model of the trip attraction / generation. Finally, the road's level of service analysis performed on the road and calculated how much influence the movement of industrial vehicles to the the road's level of service. 


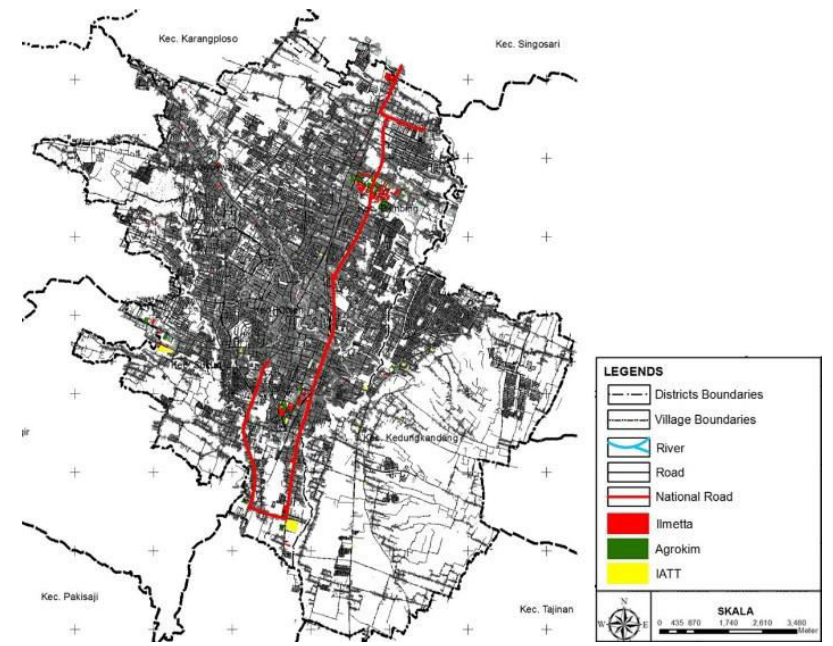

Figure 4. Industrial distribution in Malang City Source: Analysis, 2016

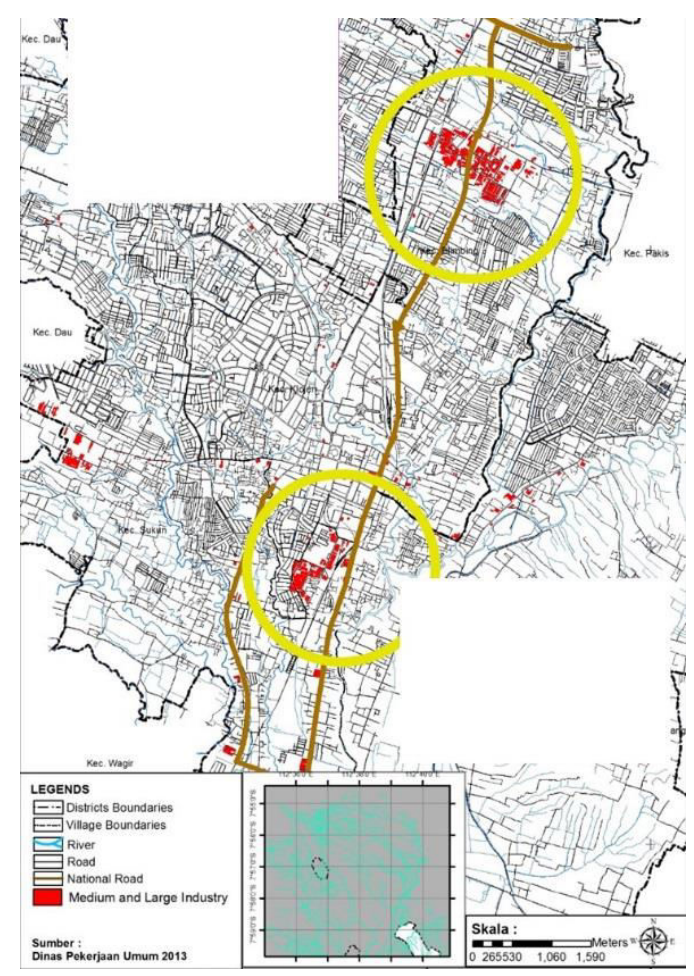

Figure 5. Selection of industry location focus Source: Analysis, 2016

\section{A. The Road's Level of Service Analysis}

The study only calculates the volume of traffic and road capacity. Based on the Highway Capacity Manual of Indonesia (HCMI, 1997), road capacity is the maximum number of vehicular traffic that can be accommodated on the road during certain conditions (geometry design, environment and traffic composition) which can be determined in units of passenger cars (pcu/hour).

The degree of saturation defined as the result for the traffic flow on the road segment to the capacity of the point of degree of saturation can be used as a measure to indicate whether a particular road segment will meet capacity problems or not. The equation of degree of saturation is as follows:
$\mathrm{DS}=\mathrm{V} / \mathrm{C}$

$\begin{array}{ll}\text { Notes: } & \\ \text { Ds } & =\text { Degree of Saturation } \\ \text { V } & =\text { Volume of traffic flow (pcu/hour) } \\ \text { C } & =\text { Road capacity }(\mathrm{pcu} / \text { hour })\end{array}$

The calculation of the road's level of service is conducted at Sunandar Priyo Sudarmo Road which is the location of the selected road based on the consideration that has been done.

\section{B. Multiple Linear Regression}

Linear regression analysis is one of the statistical methods used to find the relevance of more than one independent variable (Miro, 2004: 71). The first step in the regression analysis phase is the selection of variables used as independent variables or dependent variables.

Here are indepedent variables of industry:

$\mathrm{Y}_{1}=$ Number of Movements

$\mathrm{X}_{1}=$ Building Area

$\mathrm{X}_{2}=$ Parking Area

$\mathrm{X}_{3}=$ Number of Employees

$\mathrm{X}_{4}=$ Visitors Count

$\mathrm{X}_{3}=$ Number of Shifts

$\mathrm{X}_{4}=$ Frequency of Delivery

$Y=a+b_{1} X_{1}+b_{2} X_{2}+\cdots+b_{n} X_{n}$

Information:

$\mathrm{Y}$ : The dependent variable in this study is the number of movements

A: Constant parameter (constanta parameter) which means that if all independent variables $\left(X_{1}\right.$ through $\left.X_{4}\right)$ remain unchanged or remain zero, then $Y_{1}$ will be equal to the constant

$\mathrm{B}_{\mathrm{n}}$ : Parameter coefficient (coefficient parameter) in the form of values that will be used to determine the effect of variables on the number of movements

$\mathrm{X}_{\mathrm{n}}$ : Independent variables are all factors included in the model and which may affect the number of movements.

\section{Partial Correlation Analysis}

This research was conducted by using several independent variables that will be tested by using multiple linear regression. Associated with the matter it is necessary to do correlation analysis to determine how the level of correlation of independent variables with the dependent variable. Direction is denoted by a positive and negative form whereas for the strength is expressed in the magnitude of the correlation coefficient.

The relationship between positive variables if one variable raised then it will increase the value of the other variable while the relationship will be negative if one variable value increased then it will decrease the value of other variables. The largest correlation coefficient is 1 , the largest negative correlation is -1 and the smallest correlation number is 0 (Table 2). 
Tabel 2. Interpretation of Correlation Coefficient

\begin{tabular}{cc}
\hline Coefficient Interval & Relationship Level \\
\hline $0,00-0,199$ & Very low \\
$0,20-0,399$ & Low \\
$0,40-0,599$ & Medium \\
$0,60-0,799$ & High \\
$0,8-1,00$ & Very high \\
\hline
\end{tabular}

There is a number called the coefficient of determination of the magnitude squares of the correlation coefficient. This coefficient is called coefficient determinant, because the variance that occurs in the dependent variable can be explained by the variance that occurs in the independent variable.

\section{Sampling}

Data were collected using a sample. The sample is part of the number and characteristics of the population. The sampling method used is the stratified random sampling, where the heterogeneous population is made into several groups. This is to enlarge the similarity of the characteristics of several samples used so that it can be seen the similarity it has. The sampling technique used is the Isaac and Michael Table has errors for population numbers of 1 per cent, 5 per cent and 10 per cent (Figure 6). This sampling technique is used when the population is known and the population studied is normally distributed or non-homogeneous (I.W. Agustin, 2017).

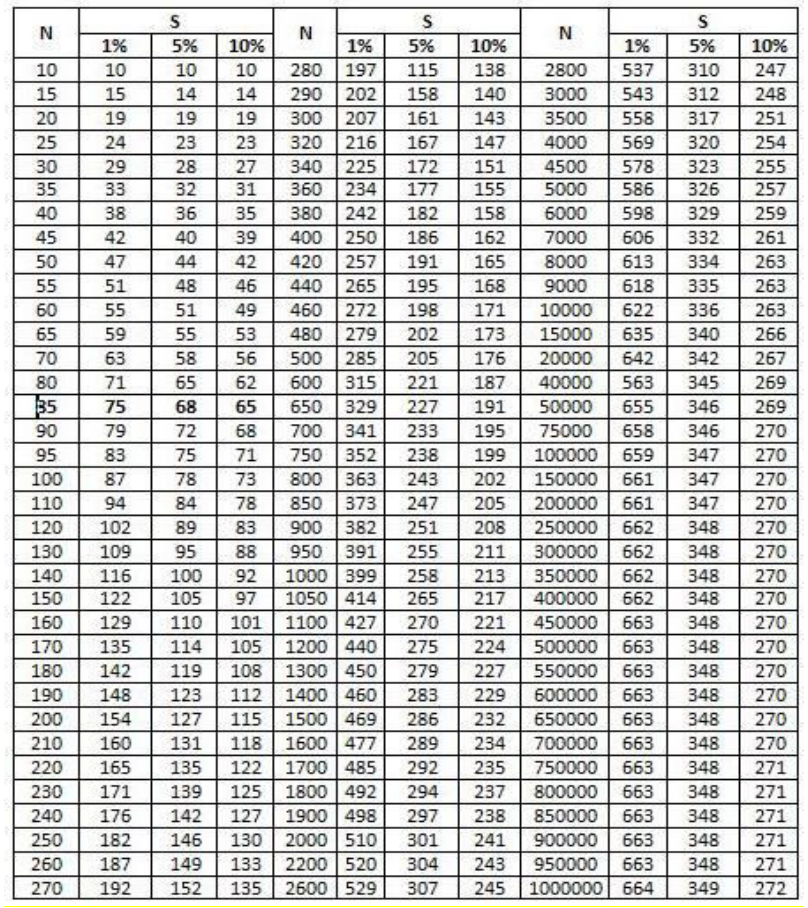

Figure 6. Isaac and Michael Table

Source: Sugiyono, 2010

\section{RESULTS AND DISCUSSION}

\section{A. Industry Characteristics}

Malang City has the characteristics of Industry with the classification of Agro Chemical Industry, Multifarious (ILMETTA), Industrial of Transportation and Telematics (IATT), Sentra and also Large Industry.
The explanation of the classification can be seen as follows:

1. ILMETA Industry:

Divided into three other classifications of Industrial Metal Basic Materials, Industrial Materials Machinery and agricultural machinery, Textile and Multifarious Industries.

2. Industrial Equipment Transportation and Telematics (IATT):

The division of industrial classification of Transportation and Telematics Equipment (IATT) is a combination of several types of industries such as the land transportation industry and Electronics and Telematics.

3. Agrochemical Industry:

Agrochemical industry is a classification of industries engaged in food processing, drinking, forest products, cigeretts and tobacco.

4. Center Industry:

Industrial center is a collection of several small industries or households that cluster in a region with the same characteristics. Industrial centers are generally engaged in the production of small and medium scale.

5. Large Industry:

It is an industry that has a large scale of production achievements such as cigarette and wood factories.

Small industry in Malang City has the largest percentage and spread throughout the district. The number of industries in the City of Malang amounted to 617 units of industry (Table 3 ).

Table 3. Distribution of Industry in the City of Malang

\begin{tabular}{ccccccc}
\hline $\begin{array}{c}\mathrm{N} \\
\mathrm{o}\end{array}$ & $\begin{array}{l}\text { Classifica } \\
\text { tion }\end{array}$ & $\begin{array}{c}\text { Suk } \\
\text { un }\end{array}$ & $\begin{array}{c}\text { Klo } \\
\text { jen }\end{array}$ & $\begin{array}{c}\text { Lowok } \\
\text { waru }\end{array}$ & $\begin{array}{c}\text { Kedung } \\
\text { Kandang }\end{array}$ & $\begin{array}{c}\text { Blim } \\
\text { bing }\end{array}$ \\
\hline 1 & ILMETA & 30 & 35 & 12 & 12 & 33 \\
2 & $\begin{array}{l}\text { IATT } \\
\text { Agroche }\end{array}$ & 12 & 10 & 6 & 9 & 11 \\
3 & $\begin{array}{l}\text { mical } \\
\text { Center }\end{array}$ & 2 & 2 & 7 & 2 & 6 \\
4 & $\begin{array}{l}\text { Industry } \\
\text { Large }\end{array}$ & 2 & - & - & - & 3 \\
\hline
\end{tabular}

Source: Analysis, 2016

Distribution of existing industries in Malang City (Table 3, Figure 1) if separated per sub-district and industry type, type of agrochemical industry is kind of industry having high distribution level. The highest is located in Klojen District with 117 units, while for large industry only located in Sukun District and Blimbing District. The dispersion of industry by District can be seen in Figure 1.

The spread of industry per district in Malang City has characteristic for Klojen District mostly spread in Kiduldalem Urban Communities with the biggest distribution that is agrokim (Figure 7). In Lowokwaru District spread almost evenly for Tulusrejo, Tunjungsekar and Tunggulwulung villages for agroindustry. Associated with many centers in Sumbersari and Merjosari one of the ceramic center Dinoyo (Figure 8). Blimbing District has many industrial dispersal due to 
Blimbing is allocation of industrial activity placement (Figure 9).

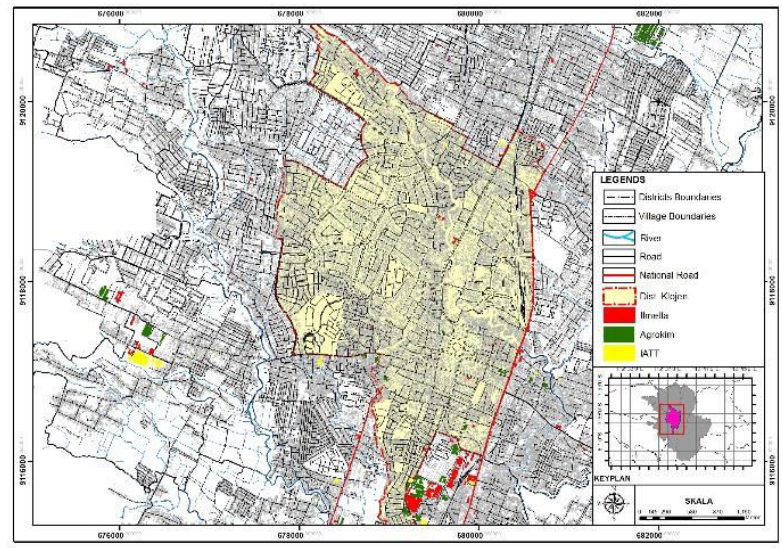

Figure 7. Industry distribution in Klojen District

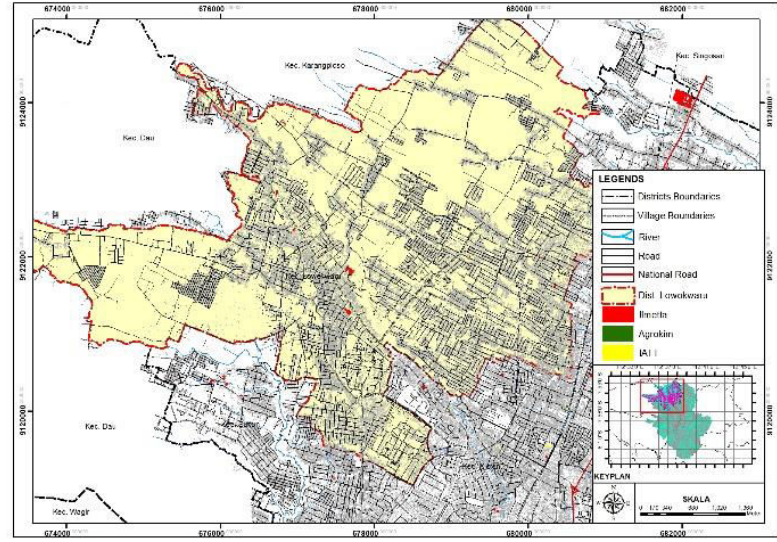

Figure 8. Industry distribution in Lowokwaru District

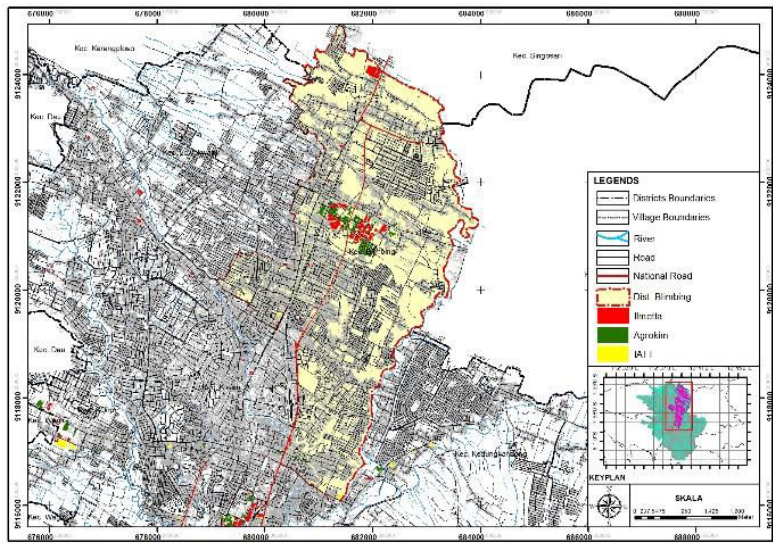

Figure 9. Industry distribution in Blimbing District

The distribution of industry in Sukun District is still relatively even for every District, which is mostly in Bandungrejosari with small industry type. While for Kedungkandang District, the distribution is more centered in KotaLama Urban Communities with Agrokim number which is 16 industrial units.

\section{B. Trip Attraction Model}

In the calculation and analysis of movement conducted in Sunandar Priyo Sudarmo Road can be classified land use activities ie industry, health, offices, commercials. In the calculation of regression analysis included variables that affect the use of the land. The result of regression analysis is known that:

a) Trip attraction model of industry

$\mathrm{Y}_{\text {industry }}=5,104+0,736\left(\mathrm{X}_{3}\right)+1,832\left(\mathrm{X}_{6}\right)$

Information:

$\mathrm{Y}$ industry $=$ dependent variable, number of movements $\mathrm{X}_{3}=$ Independent variable, number of employees $\mathrm{X}_{6}=$ Independent variable, delivery frequency The amount of $\mathrm{R}$ square for regression model that is done that is equal to 0.941 which means 94.1 per cent influence of independent variable to dependent variable.

b) Trip attraction model of Health, office and commercials.

$$
\begin{aligned}
& Y_{\text {health }}=12,545+0.277\left(\mathrm{X}_{10}\right)+0.364\left(\mathrm{X}_{11}\right) \\
& \mathrm{Y}_{\text {offices }}=38.076+0.19\left(\mathrm{X}_{12}\right)+0.301\left(\mathrm{X}_{15}\right) \\
& Y_{\text {shop }}=4,766+0,445\left(\mathrm{X}_{16}\right)+0,049\left(\mathrm{X}_{19}\right) \\
& \mathrm{Y}_{\text {store building and furniture }}=37,958+0,463\left(\mathrm{X}_{20}\right)+0,14\left(\mathrm{X}_{23}\right) \\
& Y_{\text {workshop }}=2,074+0,252\left(\mathrm{X}_{24}\right)+0,702\left(\mathrm{X}_{27}\right) \\
& Y_{\text {diners and stalls }}=1.811+1.84\left(\mathrm{X}_{31}\right)+0.443\left(\mathrm{X}_{32}\right) \\
& Y_{\text {electronics \& electrical stores }}=4,359+0,206\left(\mathrm{X}_{33}\right)+0,459\left(\mathrm{X}_{36}\right) \\
& Y_{\text {dealer } / \text { showroom }}=13,189+0,23\left(\mathrm{X}_{38}\right)+0,392\left(\mathrm{X}_{42}\right) \\
& Y_{\text {others }}=7,678+0,662\left(\mathrm{X}_{46}\right)
\end{aligned}
$$

Tabel 4. Total Movement of Land Use

\begin{tabular}{ccccc}
\hline \multirow{2}{*}{ Time } & \multicolumn{4}{c}{ Total movement of land use } \\
\cline { 2 - 5 } & Industry & Healthy & Offices & Commercials \\
\hline $\begin{array}{c}08.00- \\
09.00\end{array}$ & 316.68 & 2.80 & 19.32 & 482.36 \\
$09.00-$ & 180.96 & 6.40 & 33.12 & 533.38 \\
10.00 & & & & \\
$10.00-$ & 180.96 & 5.20 & 27.60 & 600.61 \\
11.00 & & & & \\
$11.00-$ & 158.34 & 2.80 & 30.36 & 758.91 \\
12.00 & & & & \\
$12.00-$ & 180.96 & 4.40 & 41.40 & 664.95 \\
13.00 & 180.96 & 4.00 & 38.64 & 744.5 \\
$13.00-$ & & & & \\
14.00 & 203.58 & 1.60 & 30.36 & 625.01 \\
$14.00-$ & & & & \\
15.00 & 203.58 & 4.80 & 24.84 & 494.87 \\
$15.00-$ & 316.68 & 4.40 & 19.32 & 421.79 \\
16.00 & 339.30 & 3.60 & 11.04 & 222.56 \\
$16.00-$ & & & 276.00 & $5,548.94$ \\
\hline 17.00 & $2,262.00$ & 40.00 & & \\
$17.00-$ & & & &
\end{tabular}

C. Implementation of Trip Attraction Model in Sunandar Priyo Sudarmo Road

The application of the trip attraction model based on land use aimed to find out how much the movement of incoming and outgoing vehicles for the land. So that with the calculation can be more significant how much the number of movements that exist in each land use related to the contribution of existing volume on the road (Table 4). Calculations performed for Industry, Health, office buildings and commercials. 


$$
\begin{aligned}
& Y_{\text {industry }}=5,104+0,736\left(\mathrm{X}_{3}\right)+1,832\left(\mathrm{X}_{6}\right) \\
& \mathrm{Y}_{\text {industry }}=5,104+0,736(90)+1,832(56) \\
& \mathrm{Y}_{\text {industry }}=173,936 \approx 174 \mathrm{pcu} / \text { day }
\end{aligned}
$$

\section{CONCLUSION}

The results showed that characteristics of industries in the City of Malang is divided into 5 major classifications of Agrokim industry, ILMETTA, IATT, Sentra (Center Industry) and also Large Industries. The largest industrial distribution of Agrochemicals with an average of 18.9 per cent (53-117 units), ILMETTA 5.65 per cent (12-35 units), IATT 1.9 per cent (6-12 units), Sentra 1.23 per cent (2-7 Units) and Large Industry 0.03 per cent (0-3 units). Associated with the selection of observation locations based on predetermined criteria so that roads that fit the criteria are Sunandar Priyo Sudarmo Road.

Trip attraction model of large and medium industries that focuses on Sunandar Priyo Sudarmo Road showed that:

$\mathrm{Y}_{\text {industry }}=5,104+0,736\left(\mathrm{X}_{3}\right)+1,832\left(\mathrm{X}_{6}\right)$ with $\mathrm{R}$ square 94.1 per cent

Notes :

$\mathrm{Y}_{\text {industry }}=$ dependent variable, number of movements $\mathrm{X}_{3}=$ Independent variable, Number of employees $\mathrm{X}_{6}=$ Independent variable, Frequency of Delivery

\section{REFERENCES}

[1] Y. Fitriyani, "Structuring of Industrial Estate in Kecamatan Tongas Probolinggo District," 2006.

[2] Adisasmita, Rahardjo. 2010. Basics of Transport Economics. Yogyakarta: Graha Ilmu Press.

[3] Central Bureau of Statistics. 2011. Malang City in Figures 2011. Central Statistics Agency Malang.

[4] Decree of the Minister of Public Works No. 58 KPTS / M / 2012. Determination of Road Class Based on Carrying Capacity to Receive the Heaviest Axis of Motor Vehicle Dimension in Java and Sumatra.

[5] Herzog, Bernhard. 2013. Transport of Urban Goods in Developing Country Cities. Sustainable Transport Source Module. BMZ. Germany.

[6] I.W., Agustin and Y., Sumantri. 2017. The effect of industrial vehicles on the road's level of service of industrial area in Malang City. IOP Conf. Series: Earth and Environmental Science 70.

[7] Karyanto, Eko. 2004. The Impact of Industrial Activity on Performance of Primary Arterial Road of Banjaran-Adiwerna of tegal Regency.

[8] Law of the Republic of Indonesia no. 34 in 2006 About Street, Jakarta: Government of the Republic of Indonesia.

[9] Law of the Republic of Indonesia no. 3 in 2014 About the Industry, Jakarta: Government of the Republic of Indonesia.

[10] Miro, Fidel. 2004. Transportation Planning. Jakarta: Erlangga Press.

[11] Ministry of Finance. 2003. Business Classification of Taxpayers, Jakarta: Government of the Republic of Indonesia.

[12]Miro, Fidel. 2004. Transportation Planning. Jakarta: Erlangga Press

[13]Presidential Decree No. 41. 1996. Industry

[14] President of RI. 1996. Presidential Decree of the Republic of Indonesia No. 41 of 1996 on Industrial Estate President of RI. 2004. Presidential Regulation No. 16 of 2004 on Control of Land Utilization.
[15]__ 2006. Government Regulation republic Indonesia No. 34. Year 2006 About the road.

[16]Regional Spatial Plan for East Java, 2011-2031

[17] Regional Spatial Plan for Malang City, 2011-2031

[18]Sakti, A. 2011. Transportation and Regional Development. Yogyakarta: Graha Ilmu Press.

[19] Tamin, Z, Ofyar. 2000. Transportation Modelling and Planning. ITB. Bandung.

[20] Tamin, Ofyar, Z., Frazila, RB., 1997. Application of Interaction Concept of Land Use-Transport System in Transportation System Network Planning. Journal of Urban and Regional Planning, ITB, Vol. 8, No 3, pp. 34-52. http://digilib.itb.ac.id

[21]__. Highway Manual Capacity Indonesia. 1997

[22] Waloejo, Budi Sugiarto, 2013. Interaction Model of Land Use and Road Network. Dissertation. Brawijaya University 